\author{
A. Yu. Zuev, D. S. Tsvetkov \\ ${ }^{1}$ Ural Federal University \\ 620000, Ekaterinburg, Lenin Ave. 51, (343) 251-79-27 \\ E-mail: andrey.zuev@urfu.ru
}

\title{
Oxygen non-stoichiometry and defect structure of $\mathrm{LaMn}_{1-z} \mathrm{Cu}_{\mathbf{z}} \mathrm{O}_{3+\delta}$
}

The quantitative model analysis of the defect structure of copper doped lanthanum manganites $\mathrm{LaMn}_{1-z} \mathrm{CuzO}_{3+\delta}(z=0.05$ and 0.1$)$ was performed. In the framework of the model, the independent course of the three reactions of defect formation, including the electronic exchange between manganese and copper, completion of a lattice by the absorption of oxygen and the disproportionation of manganese was considered. It is shown that the increase in the dopant content leads to a change in the dominant electronic process. This is reflected in the lock and disproportionation and leads to the increase in the concentration of holes and decrease the concentration of electrons localized on the manganese atoms.

Keywords: lanthanum manganites; oxygen non-stoichiometry; thermodynamic characteristics of reactions; disproportionation

(C) Zuev A. Yu., Tsvetkov D. S., 2015

\section{Introduction}

The study of lanthanum manganite $\mathrm{LaMnO}_{3 \pm \delta}$ started with published in 1950, the work of Jonker and van Santena Santena [1] and has continued at present. The reason is that lanthanum manganites, partially doped alkaline earth metals, mainly calcium or strontium, are today indispensable cathode materials for high-temperature fuel cells $[1,2,3]$. Lanthanum manganites with partial substitution of manganese for other 3d-metals have been studied less.

However, the isomorphic substitution of manganese for copper leads to a substantial change of the magnetic and catalytic performance of lanthanum manganite [4], most likely due to the increased lability of the oxygen sublattice [5] and presence of 3d-metal in mixed oxidation states [4]. In his early work [6] we have analyzed the oxygen non-stoichiometry $\mathrm{LaMn}_{1-\mathrm{z}} \mathrm{Cu}_{\mathrm{z}} \mathrm{O}_{3+\delta}$ and proposed a model of its defect structure. However, quantitative analysis of this model was not performed. In this paper, we present the results of this analysis. 


\section{Theory}

As oxygen non-stoichiometry of copper substituted lanthanum manganites are studied exclusively in the area of excess oxygen, the modeling of the defect structure in these manganites is only for this area. According to Jonker [7], if in $\mathrm{LaMnO}_{3+\delta} \quad \mathrm{Mn}$ is substituted for copper, which is more electronegative 3d-metal, we should expect the reaction.

$$
M n_{M n}^{\times}+C u_{M n}^{\times}=M n_{M n}^{\circ}+C u_{M n}^{\prime}
$$

with the equilibrium constant $K_{1}=\frac{\left[M n_{M n}^{\circ}\right]\left[C u_{M n}^{\prime}\right]}{\left[M n_{M n}^{\times}\right]\left[C u_{M n}^{\times}\right]}$,

where $C u_{M n}^{\times}$и $C u_{M n}^{\prime}-\mathrm{Cu}^{+3}$ и $\mathrm{Cu}^{+2}$, accordingly recorded in the system of Kroger-Vinca. Taking into account the reaction of completing the grid

$$
6 M n_{M n}^{\times}+\frac{3}{2} \mathrm{O}_{2} \Leftrightarrow V_{L a}^{\prime \prime \prime}+V_{M n}^{\prime \prime \prime}+3 O_{O}^{\times}+6 M n_{M n}^{\circ}
$$

with the equilibrium constant

$$
K_{2}=\frac{\left[O_{O}^{\times}\right]^{3} \cdot\left[V_{L a}^{\prime \prime \prime}\right] \cdot\left[V_{M n}^{\prime \prime \prime}\right] \cdot\left[M n_{M n}^{\circ}\right]^{6}}{\left[M n_{M n}^{\times}\right]^{6} \cdot p_{O_{2}}^{3 / 2}},
$$

where $M n_{M n}^{\times}$и $M n_{M n}^{\circ}-\mathrm{Mn}^{+3}$ и $\mathrm{Mn}^{+4}$, respectively, as well as the disproportionation of manganese

$$
2 M n_{M n}^{\times} \Leftrightarrow M n_{M n}^{\circ}+M n_{M n}^{\prime}
$$

with the equilibrium constant

\section{Results and discussion}

In Fig. 1, 2 there are the dependences of the absolute oxygen non stoichiometry of substituted manganites $\mathrm{LaMn}_{1 z} \mathrm{Cu}_{z} \mathrm{O}_{3+\delta}$, where $z=0.05$ and 0.10 , respectively, from the partial pressure of oxygen and temperature.

It follows from these figures that in the whole studied range of temperatures and pressures of oxygen manganite

$$
K_{3}=\frac{\left[M n_{M n}^{\circ}\right] \cdot\left[M n_{M n}^{\prime}\right]}{\left[M n_{M n}^{\times}\right]^{2}},
$$

where $2 M n_{M n}^{\times} \Leftrightarrow M n_{M n}^{\circ}+M n_{M n}^{\prime}$, together with the relevant conditions of mass balance and electroneutrality, we obtain the system of equations that defines the model of the defect structure of $\mathrm{LaMn}_{1-z} \mathrm{Cu}_{z} \mathrm{O}_{3+\delta}$

$$
\begin{aligned}
& K_{1}=\frac{\left[M n_{M n}^{\circ}\right] \cdot\left[C u_{M n}^{\prime}\right]}{\left[M n_{M n}^{\times}\right] \cdot\left[C u_{M n}^{\times}\right]}=K_{1}^{0} \exp \left(-\frac{\Delta H_{1}}{R T}\right) \\
& K_{2}=\frac{\left[O_{O}^{\times}\right]^{3} \cdot\left[V_{L a}^{\prime \prime \prime}\right] \cdot\left[V_{M n}^{\prime \prime \prime}\right] \cdot\left[M n_{M n}^{\circ}\right]^{6}}{\left[M n_{M n}^{\times}\right]^{6} \cdot p_{O_{2}}^{3 / 2}}=K_{2}^{0} \exp \left(-\frac{\Delta H_{2}}{R T}\right) \\
& K_{3}=\frac{\left[M n_{M n}^{\circ}\right] \cdot\left[M n_{M n}^{\prime}\right]}{\left[M n_{M n}^{\times}\right]^{2}}=K_{3}^{0} \cdot \exp \left(-\frac{\Delta H_{3}}{R T}\right) \\
& 3\left[V_{M n}^{\prime \prime \prime}\right] \quad 3\left[V_{L a}^{\prime \prime \prime}\right]\left[M n_{M n}^{\prime}\right]=\left[M n_{M n}^{\circ}\right] \\
& {\left[M n_{M n}^{\circ}\right]\left[M n_{M n}^{\prime}\right]\left[M n_{M n}^{\times}\right]=\frac{(1-z) \cdot 3}{3} \delta} \\
& {\left[C u_{M n}^{\prime}\right]\left[C u_{M n}^{\times}\right]=\frac{z \cdot 3}{3 \delta}} \\
& {\left[V_{L a}^{\prime \prime \prime}\right]=\left[V_{M n}^{\prime \prime \prime}\right]=\frac{\delta}{3 \delta}} \\
& {\left[O_{O}^{\times}\right]=3}
\end{aligned}
$$

The solution of system (5) is rather complicated dependence of the general form,

$$
\begin{gathered}
\log \left(p \mathrm{O}_{2} / \mathrm{atm}\right)=f(\delta), \\
K_{3}=f(T), K_{1}=f(T), K_{2}=f(T)
\end{gathered}
$$

the explicit form which because of its bulkiness was omitted in the text.

$\mathrm{LaMn}_{0.95} \mathrm{Cu}_{0.05} \mathrm{O}_{3+\delta}$ and $\mathrm{LaMn}_{0.90} \mathrm{Cu}_{0.10} \mathrm{O}_{3+\delta}$ remain beyond stoichiometric on oxygen.

For $\mathrm{LaMn}_{0.80} \mathrm{Cu}_{0.20} \mathrm{O}_{3 \pm \delta}$ was set to [6], that the value of the oxygen content varies slightly, decreasing from 3.024 at $1173 \mathrm{~K}$ in a pure oxygen atmosphere to a value almost equal to three for $\log \left(p_{\mathrm{O} 2} /\right.$ атм $)=-2.76$ and $T=1373 \mathrm{~K}$. The sample $\mathrm{LaMn}_{0.70} \mathrm{Cu}_{0.30} \mathrm{O}_{3+\delta}$ has been investigated [6] only in the environment of air in the 
temperature interval $1173-1473 \mathrm{~K}$. The obtained data showed that in all investigated temperature interval, the sample remained stoichiometric relative to the oxygen.

In Fig. 1 and 2 the results of the verification of the model, according to equation (5), $\mathrm{LaMn}_{1-\mathrm{z}} \mathrm{Cu}_{\mathrm{z}} \mathrm{O}_{3+\delta}$ are shown using temperature dependences of the equilibrium constants (see system (4)). The parameters of the corresponding temperature dependences obtained by minimizing the deviation of model surfaces from experimental data, together with correlation coefficients are summarized in table 1 . As can be seen from this table and Fig. 1, between the values of $\mathrm{pO}_{2}$ calculated by the proposed model and defined experimentally, good agreement is observed.

It follows from table 1 that the addition of copper $(\mathrm{z}=0.05$ and 0.10$)$ in $\mathrm{LaMnO}_{3+\delta}$ practically does not change the thermodynamic characteristics of reactions of completion of construction of the lattice of perovskite (2) compared with neoperabelny manganite of lanthanum [8]. A small addition of copper $(z$ $=0.05)$ in $\mathrm{LaMnO}_{3+\delta}$ has little impact on

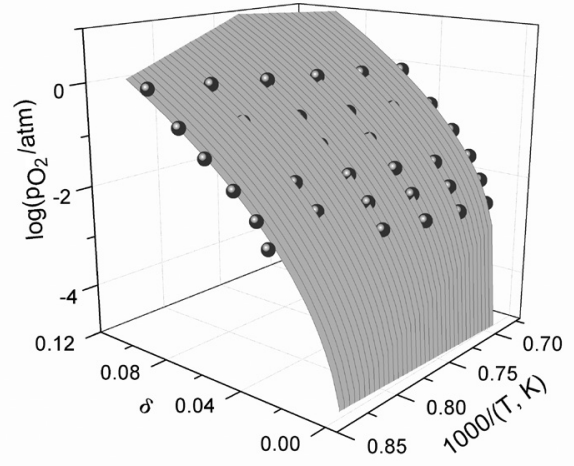

Fig. 1. The result of the model analysis of the defect structure of LaMn0.95Cu0.05O3 $+\delta$. Filled symbols - experiment [6]; surface corresponds to the equation (5) the course of the disproportionation of manganese (3), as this enthalpy of this reaction increases slightly. However, the increase in copper $(z=0.10)$ is expressed in a dramatic change in the process of disproportionation (3), which acquires a pronounced thermally activated character, as evidenced by the anomalously large value of enthalpy, $k J 6000$, compared to almost zero enthalpy of disproportionation to unsubstituted $\mathrm{LaMnO}_{3+\delta}$ [8]. It should be noted that the equilibrium constant of reaction (4) for $\mathrm{LaMn}_{0.90} \mathrm{Cu}_{0.10} \mathrm{O}_{3+\delta}$ in the temperature interval investigated takes extremely low values, varying from 10 to 60 at $1173 \mathrm{~K}$ up to $1373 \mathrm{~K}$. Therefore, the equilibrium in the disproportionation of (3) is almost completely shifted to manganese ions $\mathrm{Mn}+3$. Therefore, is reasonable to simplify the model of the defect structure of $\mathrm{LaMn}_{0.90} \mathrm{Cu}_{0.10} \mathrm{O}_{3+\delta}$ by removing from consideration the disproportionation of manganese. The corresponding simplification of the system (4) leads to a relatively simple model equation.

$\log \left(p_{02} / \mathrm{atm}\right)=-\frac{\left(\frac{\delta}{3+\delta}\right)^{\frac{1}{3}} \cdot \sqrt{3} \cdot\left(\frac{6 \cdot \delta}{3+\delta}-\frac{A}{2}\right) \cdot(3+\delta)}{\left(-2.7+6.9 \delta-\frac{3}{2} A-\frac{1}{2} A \delta\right) \cdot K_{2}^{\frac{1}{6}}}$,

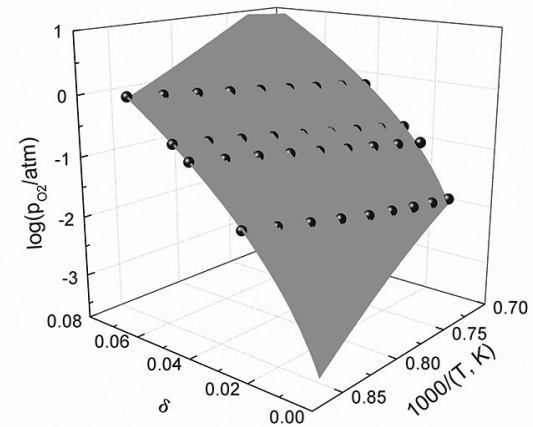

Fig. 2. The result of the model analysis of the defect structure of $\operatorname{LaMn}_{0.9} \mathrm{Cu}_{0.1} \mathrm{O}_{3+\delta^{*}}$. Filled symbols - experiment [6]; surface corresponds to the equation (5) 
where $A=\frac{7 K_{2 M n C u} \delta-6 \delta-3 K_{2 M n C u}+\sqrt{B}}{\left(K_{2 M n C u}-1\right) \cdot(3+\delta)}$ и

$B=\left(46.24 \delta^{2}+5.76-32.64 \delta\right) K_{2 M n C u}^{2}+$

$+\left(26.64 \delta^{2}+3.24-81.24 \delta\right) K_{2 M n C u}+36 \delta^{2}$

The results of the verification of a simplified model of the defect structure of $\mathrm{LaMn}_{0.90} \mathrm{Cu}_{0.10} \mathrm{O}_{3+\delta}$ according to equation (6) are also presented in table 1. As can be seen, for this model the correlation coefficient $\mathrm{R}^{2}$ was significantly closer to 1 compared with a model taking into account reaction (3). It should be added that the sum of squared deviations for the model which corresponds to equation (6) is 0.068 , while for the sought model considering reaction (3) is 0.224 . Therefore further calculations of concentrations of defects for $\mathrm{LaMn}_{0.90} \mathrm{Cu}_{0.10} \mathrm{O}_{3+\delta}$ was carried

Table 1

The values of thermodynamic parameters temperature dependences of the equilibrium constants of the processes of disordering $\mathrm{LaMn}_{1-\mathrm{z}} \mathrm{Cu}_{\mathrm{z}} \mathrm{O}_{3+\delta}$

\begin{tabular}{|c|c|c|c|c|c|}
\hline$N$ & & 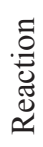 & $\Delta H, \frac{k j}{m o l}$ & $\ln \left(K_{0}\right)_{i}$ & $R^{2}$ \\
\hline \multirow{3}{*}{$\begin{array}{l}\stackrel{2}{0} \\
\dot{0}\end{array}$} & \multirow{3}{*}{5} & 3 & 85.1 & 1.53 & \multirow{3}{*}{0.996} \\
\hline & & 1 & 52.8 & 14.2 & \\
\hline & & 2 & -293.4 & -38.0 & \\
\hline \multirow{3}{*}{$\overrightarrow{0}$} & \multirow{3}{*}{5} & 3 & 6000 & 477 & \multirow{3}{*}{0.976} \\
\hline & & 1 & 118.0 & 29.3 & \\
\hline & & 2 & -242.6 & -34.2 & \\
\hline \multirow{2}{*}{$\overrightarrow{0}$} & \multirow{2}{*}{6} & 1 & $178 \pm 33$ & $14.9 \pm 3$ & \multirow{2}{*}{0.994} \\
\hline & & 2 & $-163 \pm 30$ & $-29.5 \pm 3$ & \\
\hline
\end{tabular}

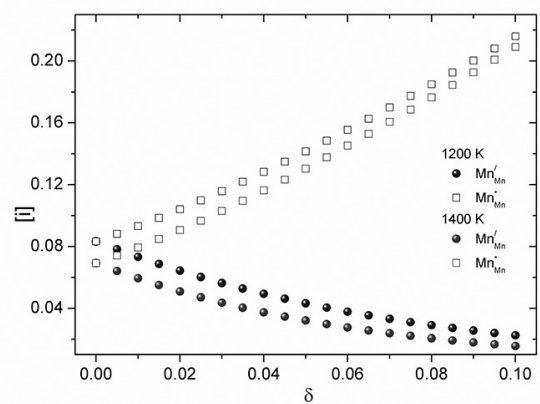

Fig. 3. The dependence of the concentration of electronic defects in $\mathrm{LaMnO}_{3+\delta}$ from oxygen non stoichiometry [8] at different temperatures

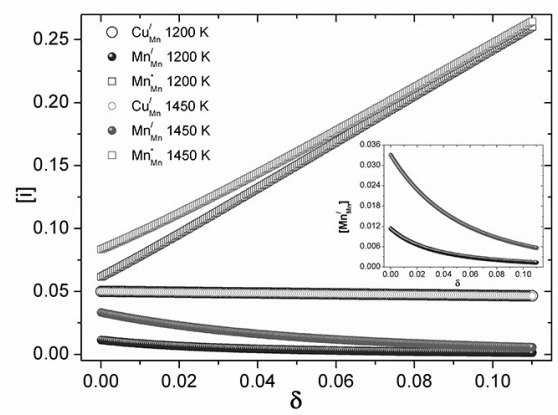

Fig. 4. The dependence of the concentration of electronic defects $\mathrm{LaMn}_{0.95} \mathrm{Cu}_{0.05} \mathrm{O}_{3+\delta}$ from oxygen non stoichiometry at different temperatures 
out on the basis of results of model analysis of equation (6).

As an example in Fig. 3-6 the dependencies of the concentration of localized electronic defects from oxygen nonstoichiometry $\mathrm{LaMn}_{1 z} \mathrm{Cu}_{z} \mathrm{O}_{3+\delta}$ are $z=0,0.05$ and 0.1 , respectively. For comparative purposes, based on the concentration of holes localized on the manganese atoms, the magnitude of $\delta$ for various compositions $\mathrm{LaMn}_{1 z} \mathrm{Cu}_{z} \mathrm{O}_{3+\delta}$ is shown in Fig. 6.

As can be seen from these drawings, the addition of copper in $\mathrm{LaMnO}_{3+\delta}$ leads to a noticeable change in the electronic disordering manganese sublattice, which is reflected in the increase in the concentration of holes and decrease of the concentration of electrons localized on the manganese atoms.

The concentration of electrons localized at the copper atoms is almost constant in the whole area of excess oxygen for manganite $\mathrm{LaMn}_{0.95} \mathrm{Cu}_{0.05} \mathrm{O}_{3+\delta}$ and does not depend on temperature, being

\section{Conclusions}

Doping of the lanthanum manganite of copper has a significant impact primarily on the oxygen content and its

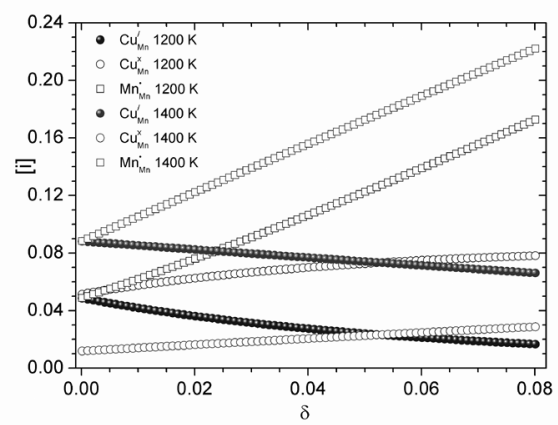

Fig. 5. The dependence of the concentration of electronic defects $\mathrm{LaMn}_{0.9} \mathrm{Cu}_{0.1} \mathrm{O}_{3+\delta}$ from oxygen non stoichiometry at different temperatures equal to the total copper content, whereas this value for $\mathrm{LaMn}_{0.90} \mathrm{Cu}_{0.10} \mathrm{O}_{3+\delta}$ varies in a wide interval when changing the oxygen content and temperature.

The observed increase in the content of $\mathrm{Mn}^{+4}$ in the lanthanum manganite when it is doped with copper is consistent with the findings of [9], made on the basis of the redox titration of samples of copper substituted lanthanum manganites. Found in the present work, the change in the concentration of $\mathrm{Cu}^{+2}$ for $\mathrm{LaMn}_{0.90} \mathrm{Cu}_{0.10} \mathrm{O}_{3+\delta}$ depending on the oxygen index and temperature beyond stoichiometric indirectly supported by the results of [10], which is obtained for this composition range $\mathrm{x}$-ray photoelectron spectroscopy was unable to decipher in the assumption that all copper is located only in the state +2 . At the same time the authors [10] found the absence of $\mathrm{Mn}^{+2}$ in $\mathrm{LaMn}_{0.90} \mathrm{Cu}_{0.10} \mathrm{O}_{3+\delta}$ is consistent with the results of the model analysis of the defect structure of the manganite which is made in the present work. electronic subsystem. This is observed in the consecutive change of the dominant electronic process from the dispropor-

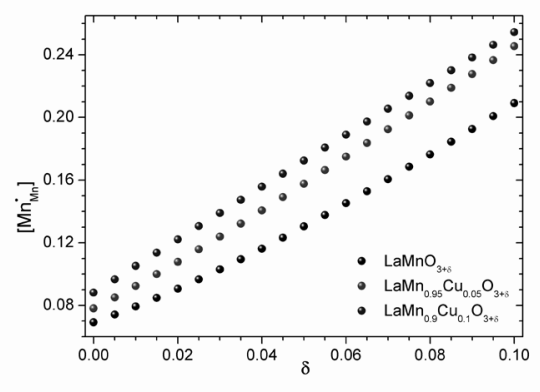

Fig. 6. The dependence of the concentration of electronic defects $\mathrm{LaMn}_{1-\mathrm{z}} \mathrm{Cu}_{\mathrm{z}} \mathrm{O}_{3+\delta}$ from oxygen non stoichiometry at different temperatures 
tionation of manganese to the reaction of the electronic exchange between the manganese and copper increases the content in $\mathrm{LaMn}_{1-z} \mathrm{Cu}_{z} \mathrm{O}_{3+\delta}$, and decrease in oxygen content. When the concentration of the dopant is $z=0.3$, the response of the electronic exchange between manganese and copper, apparently, is the only process of disordering $\mathrm{LaMn}_{1-z} \mathrm{Cu}_{z} \mathrm{O}_{3}$, that is expressed in its stoichiometric composition of oxygen in the whole studied range of temperature.

1. Jonker G. H., Van Santen J. H. Ferromagnetic compounds of manganese with perovskite structure. Physics. 1950;16;337-349.

2. N. H. Menzler, F. Tietz, S. Uhlenbruck, H. P. Buchkremer, D. Stöver. Materials and manufacturing technologies for solid oxide fuel cells. J. Mater. Sci. 2010;45:31093135.

3. Santen J. H. van Jonker G. H. Electrical conductivity of ferromagnetic compounds of manganese with perovskite structure. Physics. 1950;16:599-600.

4. Royer S., Duprez D. Catalytic Oxidation of Carbon Monoxide over Transition Metal Oxides. ChemCatChem. 2011;3:24-65.

5. Chan K. S., Jaenicke S., Chuah G. K. and Lee J. Y. Catalytic carbon monoxide oxidation over strontium, cerium and copper-substituted lanthanum manganates and cobaltates. Applied Catalysis A: General. 1994;107:201-207.

6. Petrov A. N., Zuev A. Yu., Tikchonova I. L. Voronin V. I. Crystal and defect structure of the mixed oxides $\mathrm{LaMn}_{1-z} \mathrm{Cu}_{z} \mathrm{O}_{3 \pm y}(0 £ z \leq 0.4)$. Solid State Ionics. 2000;129:179-188.

7. Jonker G. H. Magnetic and Semiconducting Properties of Perovskites Containing Manganese and Cobalt. J. Appl. Phys. 1966;37:1424-1430.

8. Zuev A. Yu., Tsvetkov D. S. Oxygen nonstoichiometry, defect structure and defectinduced expansion of undoped perovskite $\mathrm{LaMnO}_{3 \pm \delta}$. Solid State Ionics. 2010;81:557563.

9. Porta P., De Rossi S., Faticanti M., Minelli G., Pettiti I., Lisi L., Turco M. PerovskiteType Oxides I. Structural, Magnetic, and Morphological Properties of $\mathrm{LaMn}_{1-x}$ $\mathrm{Cu}_{x} \mathrm{O}_{3-\mathrm{d}}$ and $\mathrm{LaCo}_{1-x} \mathrm{Cu}_{x} \mathrm{O}_{3-\mathrm{d}}$ Solid Solutions with Large Surface Area. J. of Solid State Chemistry. 1999;146:291-304.

10. Tabata K., Hirano Y., Suzuki E. XPS studies on the oxygen species of $\mathrm{LaMn}_{1 x} \mathrm{Cu}_{x} \mathrm{O}_{3+\lambda}$. Applied Catalysis A: General. 1998;170:245-254. 


\author{
А. Ю. Зуев, Д. С. Цветков \\ ${ }^{1}$ Уральский федеральный университет, \\ 620000, Екатеринбург, пр. Ленина 51, \\ тел. (343) 251-79-27 \\ E-mail: andrey.zuev@urfu.ru
}

\title{
Кислородная нестехиометрия и дефектная структура $\mathrm{LaMn}_{1-\mathrm{z}} \mathrm{Cu}_{\mathrm{z}} \mathrm{O}_{3+\delta}$
}

Выполнен количественный модельный анализ дефектной структуры допированных медью манганитов лантана $\mathrm{LaMn}_{1-z} \mathrm{Cu}_{z} \mathrm{O}_{3+\delta}(z=0,05$ и 0,1). В рамках модели рассмотрено независимое протекание трех реакций дефектообразования, включая электронный обмен между марганцем и медью, достраивание решетки при поглощении кислорода и диспропорционирование марганца. Показано, что увеличение содержания допанта приводит к смене доминирующего электронного процесса. Это выражается в блокировке диспропорционирования и ведет к увеличению концентрации дырок и уменьшению концентрации электронов, локализованных на атомах марганца.

Ключевые слова: манганит лантана; кислородная нестихиометрия; термодинамические характеристики реакций; диспропорционирование.

(C) Зуев А. Ю., Цветков Д. С., 2015

\section{Введение}

Исследование манганита лантана $\mathrm{LaMnO}_{3 \pm \delta}$ началось с опубликованной в 1950 г. работы Джонкера и Ван Сантена [1] и продолжается в настоящее время. Это определяется тем, что манганиты лантана, частично допированные щелочноземельными металлами, главным образом кальцием или стронцием, являются сегодня незаменимыми катодными материалами для высокотемпературных топливных элементов [1, 2, 3]. Манганиты лантана с частичной заменой марганца на другие 3d-металлы изучены в меньшей степени.

Однако изоморфное замещение марганца на медь приводит к существенному изменению магнитных и каталитических характеристик манганита лантана [4], что, наиболее вероятно, связано с увеличением лабильности кислородной подрешетки [5] и нахождением 3d-металлов в смешанных степенях окисления [4]. В своей ранней работе [6] мы проанализировали кислородную нестехиометрию $\mathrm{LaMn}_{1-z} \mathrm{Cu}_{z} \mathrm{O}_{3+\delta}$ и предложили модель его дефектной структуры. Однако количественного анализа этой модели не выполняли. В настоящей рботе мы приводим результаты этого анализа. 


\section{Теория}

Так как кислородная нестехиометрия медью замещенных манганитов лантана исследована исключительно в области избытка кислорода, то моделирование дефектной структуры этих манганитов приводится только для этой области. Согласно Джонкеру [7], если $\mathrm{Mn}$ в $\mathrm{LaMnO}_{3+\delta}$ замещается на медь, которая является более электроотрицательным 3d-металлом, то следует ожидать протекания реакции

$$
M n_{M n}^{\times}+C u_{M n}^{\times}=M n_{M n}^{\circ}+C u_{M n}^{\prime}
$$

с константой равновесия

$$
K_{1}=\frac{\left[M n_{M n}^{\circ}\right]\left[C u_{M n}^{\prime}\right]}{\left[M n_{M n}^{\times}\right]\left[C u_{M n}^{\times}\right]},
$$

где $C u_{M n}^{\times}$и $C u_{M n}^{\prime}-\mathrm{Cu}^{+3}$ и $\mathrm{Cu}^{+2}$, соответственно, записанные в системе Крёгера Винка. Приняв во внимание реакцию достраивания решетки

$$
6 M n_{M n}^{\times}+\frac{3}{2} O_{2} \Leftrightarrow V_{L a}^{\prime \prime \prime}+V_{M n}^{\prime \prime \prime}+3 O_{O}^{\times}+6 M n_{M n}^{\circ}
$$

с константой равновесия

$$
K_{2}=\frac{\left[O_{O}^{\times}\right]^{3} \cdot\left[V_{L a}^{\prime \prime \prime}\right] \cdot\left[V_{M n}^{\prime \prime \prime}\right] \cdot\left[M n_{M n}^{a}\right]^{6}}{\left[M n_{M n}^{\times}\right]^{6} \cdot p_{O_{2}}^{3 / 2}},
$$

где $M n_{M n}^{\times}$и $M n_{M n}^{\circ}-\mathrm{Mn}^{+3}$ и $\mathrm{Mn}^{+4}$, соответственно, а также диспропорционирование марганца $2 M n_{M n}^{\prime} \Leftrightarrow M n_{M n}+M n_{M n}^{\prime}$ (3)

с константой равновесия

\section{Результаты и обсуждение}

На рис. 1, 2 приведены зависимости абсолютной кислородной нестехиометрии замещенных манганитов $\mathrm{LaMn}_{1 \mathrm{z}} \mathrm{Cu}_{\mathrm{z}} \mathrm{O}_{3+\delta}$, где $z=0,05$ и 0,10 , соответственно, от парциального давления кислорода и температуры. Из этих рисунков следует, что во всем исследованном интервале темпера-
$K_{3}=\frac{\left[M n_{M n}^{\circ}\right] \cdot\left[M n_{M n}^{\prime}\right]}{\left[M n_{M n}^{\times}\right]^{2}}$,

где $M n_{M n}^{\prime}-M n^{+2}$, вместе с соответствующими условиями баланса массы и электронейтральности, получаем систему уравнений, определяющую модель дефектной структуры $\mathrm{LaMn}_{1-\mathrm{z}} \mathrm{Cu}_{\mathrm{z}} \mathrm{O}_{3+\delta}$

$$
\begin{aligned}
& K_{1}=\frac{\left[M n_{M n}^{\circ}\right] \cdot\left[C u_{M n}^{\prime}\right]}{\left[M n_{M n}^{\times}\right] \cdot\left[C u_{M n}^{\times}\right]}=K_{1}^{0} \exp \left(-\frac{\Delta H_{1}}{R T}\right) \\
& K_{2}=\frac{\left[O_{O}^{\times}\right]^{3} \cdot\left[V_{L a}^{\prime \prime \prime}\right] \cdot\left[V_{M n}^{\prime \prime \prime}\right] \cdot\left[M n_{M n}^{\circ}\right]^{6}}{\left[M n_{M n}^{\times}\right]^{6} \cdot p_{O_{2}}^{3 / 2}}=K_{2}^{0} \exp \left(-\frac{\Delta H_{2}}{R T}\right) \\
& K_{3}=\frac{\left[M n_{M n}^{\circ}\right] \cdot\left[M n_{M n}^{\prime}\right]}{\left[M n_{M n}^{\times}\right]^{2}}=K_{3}^{0} \cdot \exp \left(-\frac{\Delta H_{3}}{R T}\right) \\
& 3\left[V_{M n}^{\prime \prime \prime}\right] \quad 3\left[V_{L a}^{\prime \prime \prime}\right]\left[M n_{M n}^{\prime}\right]=\left[M n_{M n}^{\circ}\right] \\
& {\left[M n_{M n}^{\circ}\right]\left[M n_{M n}^{\prime}\right]\left[M n_{M n}^{\times}\right]=\frac{(1-z) \cdot 3}{3} \delta} \\
& {\left[C u_{M n}^{\prime}\right] \quad\left[C u_{M n}^{\times}\right]=\frac{z \cdot 3}{3} \delta} \\
& {\left[V_{L a}^{\prime \prime \prime}\right]=\left[V_{M n}^{\prime \prime \prime}\right]=\frac{\delta}{3 \delta}} \\
& {\left[O_{O}^{\times}\right]=3}
\end{aligned}
$$

Решением системы (5) является достаточно сложная зависимость общего вида,

$$
\begin{gathered}
\log \left(p \mathrm{O}_{2} / \mathrm{atm}\right)=f(\delta), \\
K_{3}=f(T), K_{1}=f(T), K_{2}=f(T),
\end{gathered}
$$

явный вид которой в силу своей громоздкости опущен в тексте.

тур и давлений кислорода манганиты $\mathrm{LaMn}_{0,95} \mathrm{Cu}_{0,05} \mathrm{O}_{3+\delta}$ и $\mathrm{LaMn}_{0,90} \mathrm{Cu}_{0,10} \mathrm{O}_{3+\delta}$ остаются сверхстехиометричными по кислороду.

Для $\mathrm{LaMn}_{0,80} \mathrm{Cu}_{0,20} \mathrm{O}_{3 \pm \delta}$ было установлено [6], что величина кислородного содержания варьируется незначительно, уменьшаясь от 3,024 при 


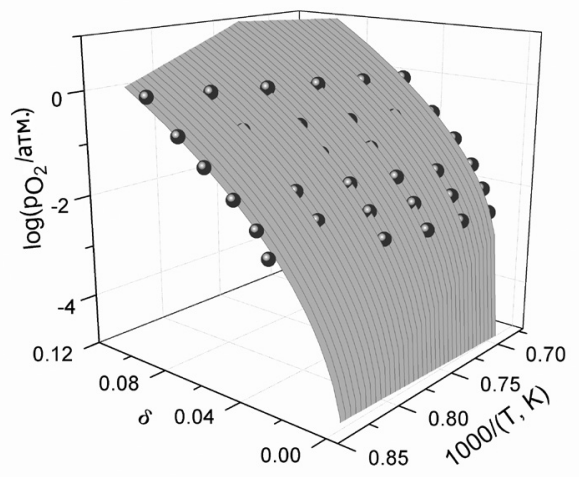

Рис. 1. Результат модельного анализа дефектной структуры $\mathrm{LaMn}_{0,95} \mathrm{Cu}_{0,05} \mathrm{O}_{3+8}$. Заполненные символы - эксперимент [6]; поверхность соответствует уравнению (5)

1173 К в атмосфере чистого кислорода до величины практически равной трем для $\log \left(\mathrm{PO}_{2} / \mathrm{aTM}\right)=-2,76$ и $T=1373$ К. Образец $\mathrm{LaMn}_{0,70} \mathrm{Cu}_{0,30} \mathrm{O}_{3+\delta}$ был исследован только в среде воздуха в температурном интервале 1173-1473 K [6]. Полученные данные показали, что во всем изученном температурном интервале образец оставался стехиометричным по отношению к кислороду.

На рис. 1 и 2 приведены результаты верификации модели, согласно уравнению (5), для $\mathrm{LaMn}_{1-\mathrm{z}} \mathrm{Cu}_{\mathrm{z}} \mathrm{O}_{3+\delta}$ с использованием температурных зависимостей констант равновесия (см. систему (4)). Параметры соответствующих температурных зависимостей, полученные в результате минимизации отклонения модельных поверхностей от экспериментальных данных, вместе с коэффициентами корреляции сведены в табл. 1. Как следует из данных этой таблицы и рис. 1, между величинами $\mathrm{pO}_{2}$, вычисленными по предложенной модели и определенными экспериментально, наблюдается хорошее согласие.

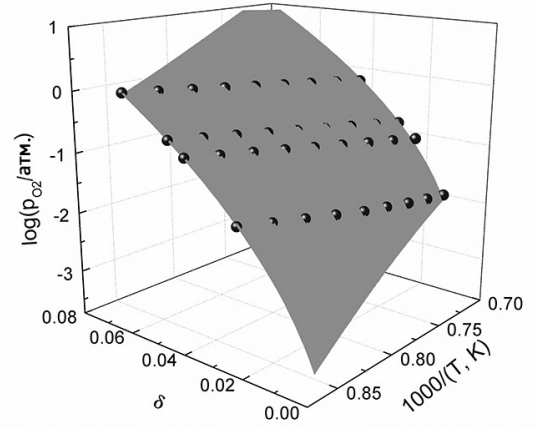

Рис. 2. Результат модельного анализа дефектной структуры $\mathrm{LaMn}_{0,9} \mathrm{Cu}_{0,1} \mathrm{O}_{3}+\delta$. Заполненные символы - эксперимент [6]; поверхность соответствует уравнению (5)

Из данных табл. 1 видно, что добавление меди $(z=0,05$ и 0,10$)$ в $\mathrm{LaMnO}_{3+\delta}$ практически не меняет термодинамические характеристики реакции достраивания решетки перовскита (2) по сравнению с недопированным манганитом лантана [8]. Небольшое добавление меди $(z=0,05)$ в $\mathrm{LaMnO}_{3+\delta}$ также имеет небольшое влияние на протекание реакции диспропорционирования марганца (3), так как при этом энтальпия этой реакции увеличивается незначительно. Однако увеличение содержания меди $(z=0,10)$ выражается в драматическом изменении процесса диспропорционирования (3), который приобретает резко выраженный термически активированный характер, о чем можно судить по аномально большому значению энтальпии, 6000 кДж, по сравнению с практически нулевой энтальпией диспропорционирования для незамещенного $\mathrm{LaMnO}_{3+\delta}$ [8]. Стоит отметить, что константа равновесия реакции (4) для $\mathrm{LaMn}_{0,90} \mathrm{Cu}_{0,10} \mathrm{O}_{3+\delta}$ в исследованном температурном интервале принимает чрезвычайно низкие значения, изменяясь от $10^{-60}$ при $1173 \mathrm{~K}$ 
Таблица 1

Значения термодинамических параметров температурных зависимостей констант равновесия процессов разупорядочения $\mathrm{LaMn}_{1-z} \mathrm{Cu}_{z} \mathrm{O}_{3+\delta}$

\begin{tabular}{|c|c|c|c|c|c|}
\hline$N$ & 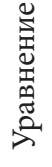 & 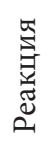 & $\begin{array}{c}\Delta H, \\
\text { кДж } \\
\text { моль }\end{array}$ & $\ln \left(K_{0}\right)_{i}$ & $R^{2}$ \\
\hline \multirow{3}{*}{0,05} & \multirow{3}{*}{5} & 3 & 85,1 & 1,53 & \multirow{3}{*}{0,996} \\
\hline & & 1 & 52,8 & 14.2 & \\
\hline & & 2 & $-293,4$ & $-38,0$ & \\
\hline \multirow{3}{*}{0,1} & \multirow{3}{*}{5} & 3 & 6000 & 477 & \multirow{3}{*}{0,976} \\
\hline & & 1 & 118,0 & 29,3 & \\
\hline & & 2 & $-242,6$ & $-34,2$ & \\
\hline \multirow{2}{*}{0,1} & \multirow{2}{*}{6} & 1 & $178 \pm 33$ & $14.9 \pm 3$ & \multirow{2}{*}{0,994} \\
\hline & & 2 & $-163 \pm 30$ & $-29,5 \pm 3$ & \\
\hline
\end{tabular}

до $10^{-22}$ при 1373 К. Следовательно, равновесие в реакции диспропорционирования (3) практически полностью смещается на ионы марганца $\mathrm{Mn}^{+3}$. Поэтому обоснованным предоставляется упрощение модели дефектной структуры $\mathrm{LaMn}_{0,90} \mathrm{Cu}_{0,10} \mathrm{O}_{3+\delta} \quad$ путем исключения из рассмотрения реакции диспропорционирования марганца. Соответствующее упрощение системы (4) приводит к относительно простому модельному уравнению

$\log \left(p_{o 2} / \mathrm{atm}\right)=-\frac{\left(\frac{\delta}{3+\delta}\right)^{\frac{1}{3}} \cdot \sqrt{3} \cdot\left(\frac{6 \cdot \delta}{3+\delta}-\frac{A}{2}\right) \cdot(3+\delta)}{\left(-2,7+6,9 \delta-\frac{3}{2} A-\frac{1}{2} A \delta\right) \cdot K_{2}^{\frac{1}{6}}}$,

где

$A=\frac{7 K_{2 M n C u} \delta-6 \delta-3 K_{2 M n C u}+\sqrt{B}}{\left(K_{2 M n C u}-1\right) \cdot(3+\delta)}$

$B=\left(46,24 \delta^{2}+5,76-32,64 \delta\right) K_{2 M n C u}^{2}+$

$+\left(26,64 \delta^{2}+3,24-81,24 \delta\right) K_{2 M n C u}+36 \delta^{2}$
Результаты верификации упрощенной модели дефектной структуры $\mathrm{LaMn}_{0,90} \mathrm{Cu}_{0,10} \mathrm{O}_{3+\delta}$ согласно уравнению (6) приводятся также в табл. 1. Как видно, для этой модели коэффициент корреляции $R^{2}$ заметно ближе к 1 по сравнению с моделью, учитывающей реакцию (3). Следует добавить, что сумма квадратов отклонений для модели, которой соответствует уравнение (6), составляет 0,068, тогда как искомое для модели, учитывающей реакцию (3) - 0,224. Поэтому дальнейшие расчеты концентраций дефектов для $\mathrm{LaMn}_{0,90} \mathrm{Cu}_{0,10} \mathrm{O}_{3+\delta}$ выполняли на основе результатов модельного анализа уравнения (6).

В качестве примера на рис. 3-6 приводятся зависимости концентрации локализованных электронных дефектов от кислородной нестехиометрии $\mathrm{LaMn}_{1-\mathrm{z}} \mathrm{Cu}_{\mathrm{z}} \mathrm{O}_{3+\delta}$ для $z=0 ; 0,05$ и $0 ; 1$, соответственно. В целях сравнения 
зависимости концентрации дырок, локализованных на атомах марганца, от величины $\delta$ для различных составов $\mathrm{LaMn}_{1-\mathrm{z}} \mathrm{Cu}_{\mathrm{z}} \mathrm{O}_{3+\delta}$ приведены на рис. 6.

Как следует из этих рисунков, добавление меди в $\mathrm{LaMnO}_{3+\delta}$ приводит к заметному изменению электронного разупорядочения марганцевой подрешетки, что выражается в увеличении концентрации дырок $M n_{M n}^{\circ}$ и уменьшении концентрации электронов $M n_{M n}^{\times}$, локализованных на атомах марганца.

Как следует из данных этих рисунков, добавление меди в $\mathrm{LaMnO}_{3+\delta}$ приводит к заметному изменению электронного разупорядочения марганцевой подрешетки, что выражается в увеличении концентрации дырок $M n_{M n}^{\circ}$ и уменьшении концентрации электронов $M n_{M n}^{\times}$, локализованных на атомах марганца. При этом концентрация электронов, локализованных на атомах меди $C u_{M n}^{\prime}$ , практически не изменяется во всей области избытка кислорода для манганита $\mathrm{LaMn}_{0,95} \mathrm{Cu}_{0,05} \mathrm{O}_{3+\delta}$, и не зависит от температуры, оставаясь равной общему содержании меди, тогда как эта

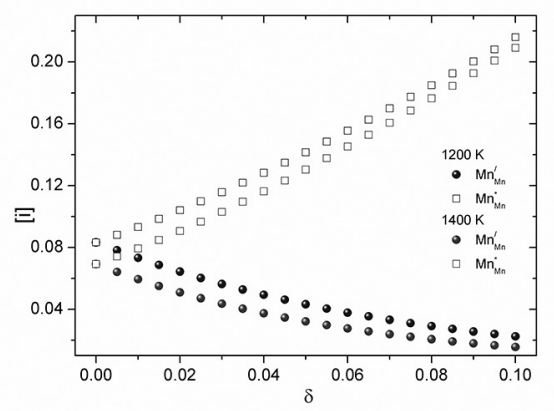

Рис. 3. Зависимость концентрации электронных дефектов $\mathrm{LaMnO}_{3}+\delta$ от кислородной нестехиометрии [8] при различных температурах величина для $\mathrm{LaMn}_{0,90} \mathrm{Cu}_{0,10} \mathrm{O}_{3+\delta}$ варьируется в широком интервале при изменении содержания кислорода и температуры.

Наблюдаемое увеличение содержания $\mathrm{Mn}^{+4}$ в манганите лантана при его допировании медью согласуется с выводами работы [9], сделанными на основании окислительно-восстановительного титрования медью образцов замещенных манганитов лантана. Обнаруженное в настоящей работе изменение концентрации $\mathrm{Cu}^{+2}$ для $\mathrm{LaMn}_{0,90} \mathrm{Cu}_{0,10} \mathrm{O}_{3+\delta}$ в зависимости от индекса кислородной сверхстехиометрии и температуры косвенно поддерживается результатами работы [10], в которой полученный для этого состава спектр рентгеновской фотоэлектронной спектроскопии не удалось расшифровать в предположении того, что вся медь находится только в состоянии +2. В то же время, установленное авторами [10] отсутствие $\mathrm{Mn}^{+2}$ в $\mathrm{LaMn}_{0,90} \mathrm{Cu}_{0,10} \mathrm{O}_{3+\delta}$ полностью согласуется с результатами модельного анализа дефектной структуры этого манганита, выполненного в настоящей работе.

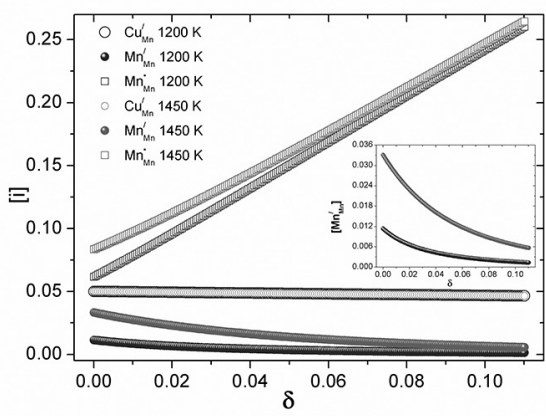

Рис. 4. Зависимость концентрации электронных дефектов $\mathrm{LaMn}_{0,95} \mathrm{Cu}_{0,05} \mathrm{O}_{3+\delta}$ от кислородной нестехиометрии при различных температурах 


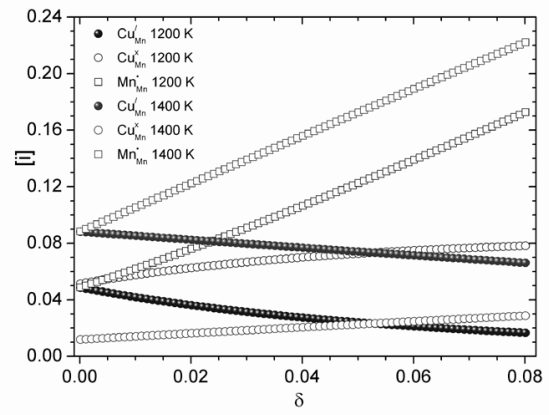

Рис. 5. Зависимость концентрации электронных дефектов $\mathrm{LaMn}_{0,9} \mathrm{Cu}_{0,1} \mathrm{O}_{3+\delta}$ от кислородной нестехиометрии при различных температурах

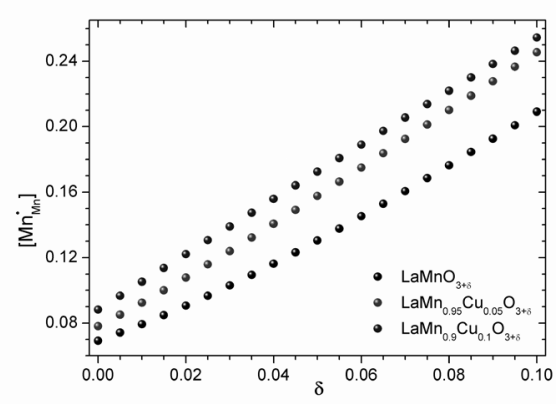

Рис. 6. Зависимость концентрации электронных дефектов $\mathrm{LaMn}_{1-z} \mathrm{Cu}_{z} \mathrm{O}_{3+\delta}$ от кислородной нестехиометрии при различных температурах

\section{Выводы}

Допирование манганита лантана медью оказывает заметное влияние прежде всего на содержание кислорода и его электронную подсистему. Это наблюдается в последовательной смене доминирующего электронного процесса с реакции диспропорционирования марганца на реакцию электронного обмена между марганцем и медью по мере увеличения содержания последней в $\mathrm{LaMn}_{1-\mathrm{z}} \mathrm{Cu}_{\mathrm{z}} \mathrm{O}_{3+\delta}$ при одновремен- ном уменьшении содержания кислорода. При достижении концентрации допанта $z=0,3$, реакция электронного обмена между марганцем и медью, по всей видимости, становится единственным процессом разупорядочения $\mathrm{LaMn}_{1-\mathrm{z}} \mathrm{Cu}_{\mathrm{z}} \mathrm{O}_{3}$, что выражается в его стехиометрическом составе по кислороду во всем исследованном интервале температуры.

1. Jonker G. H., Van Santen J. H. Ferromagnetic compounds of manganese with perovskite structure. Physics. 1950;16:337-349.

2. Menzler N. H., Tietz F., Uhlenbruck S., Buchkremer H. P., Stöver D. Materials and manufacturing technologies for solid oxide fuel cells. J. Mater. Sci. 2010;45:31093135.

3. Santen J. H. van, Jonker G. H. Electrical conductivity of ferromagnetic compounds of manganese with perovskite structure. Physics. 1950;16:599-600.

4. Royer S., Duprez D. Catalytic Oxidation of Carbon Monoxide over Transition Metal Oxides. ChemCatChem. 2011;3:24-65.

5. Chan K. S., Jaenicke S., Chuah G. K. and Lee J. Y. Catalytic carbon monoxide oxidation over strontium, cerium and copper-substituted lanthanum manganates and cobaltates. Applied Catalysis A: General. 1994;107:201-207.

6. Petrov A. N., Zuev A. Yu., Tikchonova I. L. Voronin V. I. Crystal and defect structure of the mixed oxides $\mathrm{LaMn}_{1-z} \mathrm{Cu}_{z} \mathrm{O}_{3 \pm y}(0 £ z \leq 0,4)$. Solid State Ionics. 2000;129:179-188. 
7. Jonker G. H. Magnetic and Semiconducting Properties of Perovskites Containing Manganese and Cobalt. J. Appl. Phys. 1966;37:1424-1430.

8. Zuev A. Yu., Tsvetkov D. S. Oxygen nonstoichiometry, defect structure and defectinduced expansion of undoped perovskite $\mathrm{LaMnO}_{3 \pm \delta}$. Solid State Ionics. 2010;81:557563.

9. Porta P., De Rossi S., Faticanti M., Minelli G., Pettiti I., Lisi L., Turco M. PerovskiteType Oxides I. Structural, Magnetic, and Morphological Properties of LaMn $\mathrm{Cu}_{x} \mathrm{O}_{3-\mathrm{d}}$ and $\mathrm{LaCo}_{1-x} \mathrm{Cu}_{x} \mathrm{O}_{3-\mathrm{d}}$ Solid Solutions with Large Surface Area. Journal of Solid State Chemistry. 1999;146:291-304.

10. Tabata K., Hirano Y., Suzuki E. XPS studies on the oxygen species of $\mathrm{LaMn}_{1-x} \mathrm{Cu}_{x} \mathrm{O}_{3+\lambda}$. Applied Catalysis A: General. 1998;170:245-254. 